\title{
Monoclonal Antibody IMMU-14
}

National Cancer Institute

\section{Source}

National Cancer Institute. Monoclonal Antibody IMMU-14. NCI Thesaurus. Code C29224.

An anti-carcinoembryonic antigen (anti-CEA) murine monoclonal immunog lobulin $\mathrm{G}$ ( $\lg \mathrm{G}$ ) with potential antineoplastic activity. CEA is overexpressed in several cancer cell types, including gastrointestinal, breast, and non-small cell lung cancers. MOAB IMMU-14 can be conjug ated with a radioactive element for use in radioimmunotherapy (RIT), a regimen that uses a tumor-specific monoclonal antibody to deliver targeted radiation to cancer cells. ( $\mathrm{NCl04)}$ 